\title{
Role Conflict of Trade Unions in China: A Perspective on "puppet" mechanism
}

\author{
Mengdi Li \\ Academy of Business Administration, Guangdong University of Finance and Economics, Guangzhou, \\ 510320, China
}

Keywords: We-Media, Trade union, Role conflict, Puppet mechanism.

\begin{abstract}
The most essential responsibility is keeping in close contact with the staff and protecting their rights in case of infringement since the establishment of the trade union. At the same time, the construction of the trade union is an important prerequisite to build harmonious labor relations and deal with labor disputes. However, the system of Chinese trade union is not perfect at present. In fact, there are still many problems in the process of protecting rights. The most significant is the conflict of roles of trade union. From the point of the government, the most important mission is maintaining social stability while the significance of trade union in the company is ensuring a well-regulated production environment. Of course, you can't ignore the most essential functions of the rights. The conflict of the three different status makes it difficult to determine the object of service in the process of solving the labor dispute. Although trade unions have made remarkable achievements in the course of development, however, in terms of their own identity, more similar to the "puppet", the relatively poor initiative. On the other hand, with the advent of the Internet era, the We-Media has been booming, which brings new challenges. The traditional working methods has been unable to effectively provide services, seriously hindered trade unions play a substantive role in the coordination of labor relations. Therefore, it is necessary to adjust in time to establish a more scientific, mature and stable trade union system, otherwise it will affect the credibility of trade unions, so that workers have a crisis of confidence.
\end{abstract}

\section{Introduction}

Chinese trade unions have been isolated from the masses of workers. Ruoyu Lai (1987) even believes that the separation of the masses is the biggest danger to the union. Divorced from the masses, the union has no life. The power of the trade union lies in contact with the masses. One losing the masses, the trade unions have no power. Under the social background of China, the power of trade unions comes from administrative power, which comes from the national and governmental organizations (Chen Feng, 2009).

In the early days of the founding of new China, the late 1980s and after the 21st century, the Chinese trade unions had undergone three major reforms aimed at strengthening the relationship between trade unions and the masses of workers. Some methods have been carried out such as improving relationship between government and trade unions, reducing the union's "official" color, enhancing the autonomy and vitality of trade unions and increasing the protection of the legitimate rights and interests of workers.

However, the union has been fully integrated into the government agencies, the union's primary task is to perform the duties as a government agency. When the function of economic development and maintain social stability conflict with the maintenance of labor rights, the union' s primary function is to coordinate labor relations, maintaining social stability to ensure economic development, but not the maintenance of the interests of the employees. (Bill Taylor and Qi Li, 2009).

Shouzhen Li, a member of the All-China Federation of Labor, made a speech at the New Media Seminar on "Promoting Peasant Workers 'Association and Service Work" in July 2015. "It is necessary to make great efforts to do a good job in trade unions' new media work; At the same time, 
the status of the new media to clear the trade unions to highlight the characteristics to be unique, to a more lively, more ground in the form of good talk about trade unions, workers stories, so that the new media trade unions to become the majority of workers intimate friends ". For the union, the We-Media is a challenge, but also an opportunity. The use of more convenient from the We-Media to contact the staff groups to provide more timely and effective rights services, precise positioning, rapid action to expand the influence of the masses, is undoubtedly the work of trade unions in the context of the new era of focus.

\section{Conflict of trade union roles}

\section{The function of trade union is diversified}

Although the trade union has been emphasizing its mass that on behalf of the interests of workers, but still can not get rid of the nature of the government itself. From a certain point of view, the Chinese trade unions is an extension of the national authorities at the grassroots level, reflecting the method and will of national management and intervention on the labor relations. On the other hand, the trade union is a service organization, and has no profitability. There is no deny that the most of its activities are attached to the enterprise funds, which determines the multi-status of trade union.

From the government point of view, trade unions must maintain social stability, coordinate the relationship between workers and enterprises, and reduce the probability of labor disputes. Meanwhile, on the side of the laborers, trade unions must ensure that the legitimate rights and interests of the workers are protected from infringement, and express the workers' opinions so that enhance their collective bargaining power. This is determined by the mass attribute of the trade unions. As a matter of fact, the most essential function of the trade union is it. In addition, the activities of trade unions can not affect the normal production and profits of enterprises. In some cases, trade unions even encourage employees to improve the enthusiasm of the work, which is determined by its economic dependence.

Although the original duty of the trade union was born to maintain the legitimate rights and interests of workers, but in the actual operation of the process, the function of the rights continue to be weakened, replaced by peacekeeping stability, maintenance and other derivative functions. In other words, there is no benign fusion between the rights function and the derivative function, but the phenomenon of the fault, which makes the trade union can not clearly organize the objectives, thus affecting the effective functioning of rights. Therefore, the trade union in the face of the three functions of the different requirements can only choose silent.

\section{Trade union effect}

\section{Spillover Effect}

The spillover effect of trade union means that the trade union activities not only have an impact on the organization, but also have a certain radiation effect on the external environment of the organization. With foreign trade unions only protect the interests of members, and even damage the interests of different members of the organization, Chinese trade unions not only safeguard the rights and interests of members, but also safeguard the rights and interests of non-members. Therefore, Chinese trade union system has a strong open, whether members or non-members can be protected, it has obvious positive spillover effects for non-members, if not in union membership list, still can enjoy membership rights. This is because the boundaries of the Chinese trade unions are not clear. There is no clear object of service, rather than the Western sense of the workers monopoly organization, its core interests are not provided by the members of the membership, but from the enterprise to pay the membership fee. Therefore, Chinese trade unions to provide services for members at the same time does not exclude the provision of services for non-members.

Calm Effect

It is undeniable that trade unions have played a role in protecting the rights and interests of laborers, such as the protection of the rights of migrant workers. However, trade unions can only symbolize the protection of the most basic rights and interests of workers against infringement. The trade union not 
only can not represent the workers and enterprises to negotiate, on the contrary will help enterprises to persuade workers to accept the current situation, which is the effect of trade unions to appease. This intuitively shows that trade unions represent not only the interests of workers, but also efforts to safeguard the interests of enterprises. In other words, trade unions only play a role in protecting the basic rights and interests of workers, and do not play too much substantive role in raising wages or benefits, and sometimes even have side effects.

Puppet mechanism in the trade union

Zhongwei Sun(2012) pointed out that in his study, the union just like the scarecrow. Although the formulation does not engage in collective bargaining or participate in the collective contracts, but as long as the trade union exist and symbolically carry out some condolences or cultural and recreational activities to announce their presence. In this way, the trade union can play a deterrent effect. He compared the union organization to "Scarecrow" and pointed out that the mechanism includes two features: functional symbolism and organizational ambiguity. In fact, the union is not a "symbolic" organization, on the contrary, Chinese Unions have a strong power. The reason why the Union failed to give full play to the rights of workers duty, the key does not lie in the trade union organization itself, but depends on who is owner of the Union's "control line".

Chinese trade unions have their specific social environment, which determines that trade unions can not become a complete workers monopoly organization. Compared to foreign trade unions, the duties of Chinese trade unions are more reflected in the maintenance of social order stability instead of organizing workers to strike. In other words, Chinese trade unions devote itself to reduce the occurrence of strikes, which is also the performance at the national level. In addition, Chinese trade unions have strong economic dependency on enterprises and governments. If they are completely independent, it will be difficult to carry out activities, let alone enhance the efficiency of rights.

Therefore, the trade union organization is like "puppet", in the actual operation of the multi-control. The "three forces" form by the government, enterprises and workers want to obtain "puppet" control to gain speaking right and drive the "puppet" action in accordance with self-will. As the government, enterprises and workers were manipulating the "puppet" did not make it in accordance with the unified objectives of action, resulting in trade unions at a loss, the effect is not significant.

\section{Harmonious labor relation and Requirement of trade union}

\section{Increase independence}

Essentially, the production of trade unions is solving the labor disputes, providing a good environment for social production and protecting the harmonious coexistence between employers and labor. From the analysis of the trend historical development, construction of harmonious labor relation is not a short duration of time can be achieved, but a long-term task. In this process, we should always clearly recognize the essence of the union. On the other hand, it is necessary to reflect and summarize the actual situation of trade union construction, and selectively learn from the successful experience of foreign trade unions. At the same time, to define the trade union boundaries and responsibilities. However, all of this must be based on the premise of giving the union more independence.

The independence of trade unions is not to require it to be completely divorced from the government and enterprises to form an independent monopoly organization, but to achieve the dialectical unity of the three organization, to fuse with each other and resolve the contradiction between "stability", "order" and "safeguarding rights". First, distinguish between trade union organizations and the functional departments of party and government organs. Although the trade union organization has a political function, but can not be regarded as government departments, for political services can not be political control. On the other hand, trade unions and grass-roots units, as two different stakeholders, must independently carry out personnel, financial and other work, so as not to confuse each other. Secondly, to strengthen the independence of grassroots trade unions. The work of the grassroots trade unions must have a certain degree of independence. The task can not be arranged by the higher level unions, and the subjective initiative of the grassroots trade unions should 
be strengthened. According to the actual situation and the reasonable demands and suggestions of the members, the trade union affairs shall be carried out independently. Thirdly, to ensure the independence of trade union cadres. Trade union cadres can not be appointed by the government or enterprises, but should follow the principle of fairness, openness and impartiality, according to the law union members to vote for the election. Trade union cadres responsible for the members to safeguard their legitimate rights and interests, but also to accept the supervision of members. Only trade unions have the real independence, it may be truly responsible for their own actions and consequences.

\section{From the "welfare union" to the "maintainer of workers"}

Different from the trade unions in western countries, Chinese trade unions play an important role in the government, enterprises and workers. In the planned economy period, social resources and labor management are allocated by the government, personal interests must be subordinated to the interests of the collective. In this case, the role of trade unions is similar to the "cooperation", "support" and other work, and will not be directly responsible for the workers. Therefore, in a fairly long period of time, the status and role of trade unions have been ignored by scholars and society, and even in the relevant works can not find the word "trade union".

Since the reform and opening up, China's market economic system has been gradually established and improved. The market has played a decisive role in the allocation of resources, and the dominant factors of labor allocation also from the government to the market. It must make clear that trade unions should play a full role in the coordination of labor relations and abandon original inherent image. In addition, Chinese trade unions ought to play a good spokesperson role, and effectively represent the interests of workers. At the same time, highlighting the work of trade unions, strengthening collective bargaining and signing collective contract work, enhancing the participation of labor legislation and law enforcement supervision. On the other hand, to guide the workers to correctly understand and recognize the trade union so that enhance the understanding of cooperation between each other. Moreover, trade unions should promote the mutual benefit of enterprise and the staff and ensure the orderly implementation of harmonious labor relations by means of the implementation of the staff congress system, employee directors and supervisors system and so on.

\section{Integrated applications of Micro-blog and WeChat}

Providing good information and services for employees is the basis for the sustained and healthy development of the new media platform of trade unions. The open background application editor function of the WeChat public platform makes it possible to provide real-time services to the stakeholders. Trade unions can build an interactive service platform on the WeChat public platform in line with their own services. "Shen Gong Society" WeChat public platform to build a "service hall", among the rights and jobs as the core to provide the appropriate services for the staff. In the "I want to defend" plate, workers can inquiry some questions about rights protection online and the reply is timely. In addition, the relevant laws and regulations can also be found in the "service hall" plate. Besides, in the "I want to work" section which integrates job search resources that job seekers can fill out their own resume online. Furthermore, the platform also provides some entrances of union membership services card, mutual security, staff assistance and other functions of the query and cultural and sports activities. It' s a platform that covering all aspects of life for workers.

Sina Micro-blog is the most representative of the new media platform in recent years in China, has become an objective existence in the mass media. After the Micro-blog and WeChat public platform built and stored the corresponding content and service information, Micro-blog platform and its extensive publicity effect can facilitate its promotion. All users on the network have no status or wealth differences, so it is not easy to become the opinion leader in a certain field or industry. Trade union micro-blog should pay more attention to these opinion leaders, forward their posts, communicate and collaborate with them. At the same time let them on their own micro-blog propagandize unions' micro-blog. In addition, in the new network context, trade unions will win 
more attention if they can have a good interaction with the "opinion leaders", but also successfully gain more fans.

\section{References}

[1] Alex Pravda and Blair Ruble. Communist Trade Unions: Varieties of Dualism, In Alex Pravda and Blair Ruble,(eds.),Trade Unions in Communist States, Boston: Allen\&Unwin,1986,pp.1-22.

[2] Bill Taylor and Li Qi, Is the ACFTU a Union and Does it Matter? Journal of Industrial Relations, 49(5), 2007.

[3] Chen Feng. Union Power in China: Source, Operation, and Constraints, Modern China, 35(6), 2009.

[4] Li Lidong. A Review of Studies on the Function of Trade Unions in China at Home and Abroad, CASS Journal of Political Science, 2012(5):92-101.

[5] Li Min, Zhou Lian. Labor Relations Climate, Perceived Psychological Contract Breach and Union Commitment: The Cross-Level Moderating Effect of Democratic Grassroots Union Election, Chinese Journal of Management, 2015,12(3):364-371.

[6] Sun Zhongwei, He Xiaxu. Trade Union Construction and Protection of Migrant Workers' Rights and Interests - Also on a "Scarecrow Mechanism", Management World, 2012(12):46-60.

[7] The 38th China Internet Development Statistics Report, China Internet Network Information Center,2016.

[8] Wang Dongyu, Liu Tong. An Exploration of the Development of Western Union Theory and its Enlightenment to China, CPC History Studies, 2012(11):112-120.

[9] $\mathrm{Xu}$ Xiaojun. Trade Union's Corporation and Game in Building up Harmonious Labor Relations in China, JOURNAL OF CHINA INSTITUTE OF INDUSTRIAL RELATIONS, 2011,25(1):1-6. 